\title{
Renoprotective effect of edaravone in acute limb ischemia/reperfusion injury
}

\author{
Akut alt ekstremite iskemi-reperfüzyon hasarında edaravonun renal koruyucu etkisi

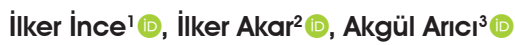 \\ Institution where the research was done: \\ Gaziosmanpaşa University Faculty of Medicine, Tokat, Turkey \\ Author Affiliations: \\ 'Department of Cardiovascular Surgery, Dışkapı Training and Research Hospital, Ankara, Turkey \\ 2Department of Cardiovascular Surgery, Gaziosmanpaşa University Faculty of Medicine, Tokat, Turkey \\ ${ }^{3}$ Department of Pathology, Gaziosmanpaşa University Faculty of Medicine, Tokat, Turkey
}

\begin{abstract}
Background: In this experimental study, we aimed to investigate the efficacy of edaravone on renal injury due to acute lower limb ischemia/reperfusion in a rat model.

Methods: Between June 2015 and August 2015, a total of 40 male Wistar rats were used in this study. The rats were randomly divided into the sham, ischemia/reperfusion, edaravone, and solvent groups ( $\mathrm{n}=10$ in each). The infrarenal abdominal aorta was clamped for $120 \mathrm{~min}$ and was, then, reperfused for $120 \mathrm{~min}$ after clamp removal. Edaravone was administered intravenously $30 \mathrm{~min}$ before the induction of ischemia. Serum and kidney tissue samples were subjected to biochemical and histopathological analyses.

Results: Edaravone decreased the serum and tissue malondialdehyde levels in the ischemia/reperfusion group. The serum superoxide dismutase activity in the edaravone group was significantly higher than the ischemia/reperfusion and solvent groups. The serum nitric oxide level in the ischemia/reperfusion group was numerically higher than the sham group. The serum nitric oxide level was decreased by edaravone. The serum nitric oxide level was lower in the edaravone group than the solvent group. The tissue nitric oxide level was significantly higher in the ischemia/reperfusion than the sham group. In the ischemia/ reperfusion group, the histopathological changes were improved by edaravone.
\end{abstract}

Conclusion: Edaravone ameliorated renal injury caused by lower-limb ischemia/reperfusion. Therefore, it can be used to ameliorate acute ischemia/reperfusion injury during aortic and peripheral vascular surgery.

Keywords: Edaravone, ischemia/reperfusion injury, lower limb, renal.

\section{$\ddot{O} Z$}

Amaç: Bu deneysel çalışmada, sıçan modelinde akut alt ekstremite iskemi/reperfüzyonuna bağlı böbrek hasarında edaravonun etkinliği araştırıldı.

Çalışma planı: Bu çalışmada Haziran 2015 - Ağustos 2015 tarihleri arasında toplam 40 erkek Wistar sıçan kullanıldı. Siçanlar sham, iskemi/reperfüzyon, edaravon ve solvent gruplarına randomize edildi ( $\mathrm{n}=10$ her bir grupta). İnfrarenal abdominal aort $120 \mathrm{dk}$. süreyle klemlendi ve sonrasında klemp kaldırılarak $120 \mathrm{dk}$. reperfüze edildi. İskemi indüksiyonundan $30 \mathrm{dk}$. önce edaravon intravenöz olarak verildi. Serum ve böbrek doku örnekleri biyokimyasal ve histopatolojik olarak analiz edildi.

Bulgular: Edaravon serum ve doku malondialdehit düzeylerini iskemi/reperfüzyon grubunda azaltt1. Serum süperoksit dismutaz aktivitesi, iskemi/reperfüzyon ve solvent gruplarına kıyasla, edaravon grubunda anlamlı düzeyde yüksekti. Serum nitrik oksit düzeyi iskemi/reperfüzyon grubunda, sham grubuna kıyasla, rakamsal olarak yüksek bulundu. Edaravon serum nitrik oksit düzeyini düşürdü. Serum nitrik oksit düzeyi edaravon grubunda, solvent grubundan, daha düşük idi. Doku nitrik oksit düzeyi iskemi/reperfüzyon grubunda, sham grubundan, anlamlı düzeyde daha yüksek idi. İskemi/ reperfüzyon grubunda histopatolojik değişikliklerde edaravon ile düzelme görüldü.

Sonuç: Edaravon alt ekstremite iskemi/reperfüzyonuna bağlı renal hasarı azaltt1. Bu nedenle, aort ve periferik damar cerrahisinde akut iskemi/reperfüzyon hasarını hafifletmede kullanılabilir.

Anahtar sözcükler: Edaravon, iskemi/reperfüzyon hasarı, alt ekstremite, böbrek.

Received: October 22, 2019 Accepted: January 28, 2020 Published online: April 22, 2020

Correspondence: İlker Akar, MD. Gaziosmanpaşa Üniversitesi Tıp Fakültesi Kalp ve Damar Cerrahisi Anabilim Dalı, 60030 Tokat, Türkiye. Tel: +90 356 - 2129500 e-mail: ilkerakar16@yahoo.com 
Ischemia/reperfusion (I/R), defined as deficient oxygen supply followed by the restoration of blood flow, can lead to irreversible damage to tissue. In ischemic tissues, xanthine is converted to uric acid and superoxide radicals, which trigger the peroxidation of membrane lipids, resulting in increased capillary permeability and filtration. Activated leukocytes accelerate leukocyte-endothelial cell interactions, leukocyte-platelet aggregation, and activation of the complement system.$^{[1]}$ Lower limb extremity I/R injury manifests clinically as muscle edema, compartment syndrome, and muscle necrosis and dysfunction. Inflammatory mediators which enter the systemic circulation from the lower limb muscle may damage distant organs, such as the kidneys. ${ }^{[2]}$

Edaravone (MCI-186, 3-methyl-1-phenyl-2pyrazolin-5-one) is a free radical scavenger developed as a neuroprotectant for ischemic stroke ${ }^{[3]}$ that has been reported to protect against I/R injury. ${ }^{[4-6]} \mathrm{In}$ this experimental study, we aimed to investigate the renoprotective effect of edaravone in rats with acute limb I/R injury.

\section{MATERIALS AND METHODS}

Between June 2015 and August 2015, a total of 40 male Wistar rats were used in this study. The rats were randomly divided into four groups $(\mathrm{n}=10$ in each) as follows: Group 1 (sham): Laparotomy was performed without aortic occlusion; Group 2 (I/R): The infrarenal abdominal aorta was clamped for $120 \mathrm{~min}$ followed by reperfusion for $120 \mathrm{~min}$; Group 3 (edaravone): Edaravone at $6 \mathrm{mg} / \mathrm{kg}$ (SigmaAldrich, St. Louis, MO, USA) was administered intravenously $30 \mathrm{~min}$ before ischemia, followed by surgery as in the I/R group; Group 4 (solvent): The solvent was administered intravenously $30 \mathrm{~min}$ before ischemia, followed by surgery as in the $\mathrm{I} / \mathrm{R}$ group. Edaravone was dissolved in $1 \mathrm{~N} \mathrm{NaOH}$ and adjusted to $\mathrm{pH}$ 7.34-7.35 using $1 \mathrm{~N} \mathrm{HCl}$ for parenteral use.

The study was approved by the Animal Experimental Committee of Gaziosmanpaşa University Faculty of Medicine University, School of Medicine. All experiments were conducted in accordance with the Institutional Animal Care and Use Committee (IACUC) guidelines.

\section{Surgical technique}

Surgery was performed under anesthesia with ketamine $(50 \mathrm{mg} / \mathrm{kg})$ and xylazine $(5 \mathrm{mg} / \mathrm{kg})$ administered intraperitoneally without endotracheal intubation or mechanical ventilation. The infrarenal abdominal aorta was explored by a transperitoneal approach via midline laparotomy. Heparin $(400 \mathrm{U} / \mathrm{kg})$ was administered to prevent coagulation. An atraumatic microvascular clamp was placed on the infrarenal abdominal aorta for $120 \mathrm{~min}$, and laparotomy incision was closed with $3 / 0$ silk sutures. Subsequently, reperfusion was carried out for $120 \mathrm{~min}$. After clamping, aortic ischemia was monitored as the loss of pulsation, and reperfusion was monitored as the presence of aortic pulsation after removing the clamp. Blood was removed by intracardiac puncture, transferred to biochemistry gel tubes, and centrifuged. The resulting serum was stored at $-80^{\circ} \mathrm{C}$. Then, both kidneys were excised: one was transferred to $10 \%$ formaldehyde solution for pathological examination and the other was stored at $-80^{\circ} \mathrm{C}$.

\section{Biochemical examination}

Superoxide dismutase (SOD) and glutathione peroxidase (GPx) activities and malondialdehyde (MDA) and nitric oxide (NO) levels were measured using a Superoxide Dismutase Assay Kit, Glutathione Peroxidase Assay Kit, TBARS Assay Kit, and Nitrate/ Nitrite Colorimetric Assay Kit, respectively (all from Cayman Chemical Ann Arbor, MI, USA) according to the manufacturer's instructions.

The kidney tissue was weighed and homogenized in $50 \mathrm{mM}$ phosphate buffer (pH 7.4) for 2 min using an Ultra-Turrax IKA T 18 homogenizer. The SOD and GPx activities and MDA and NO levels were assayed as described above.

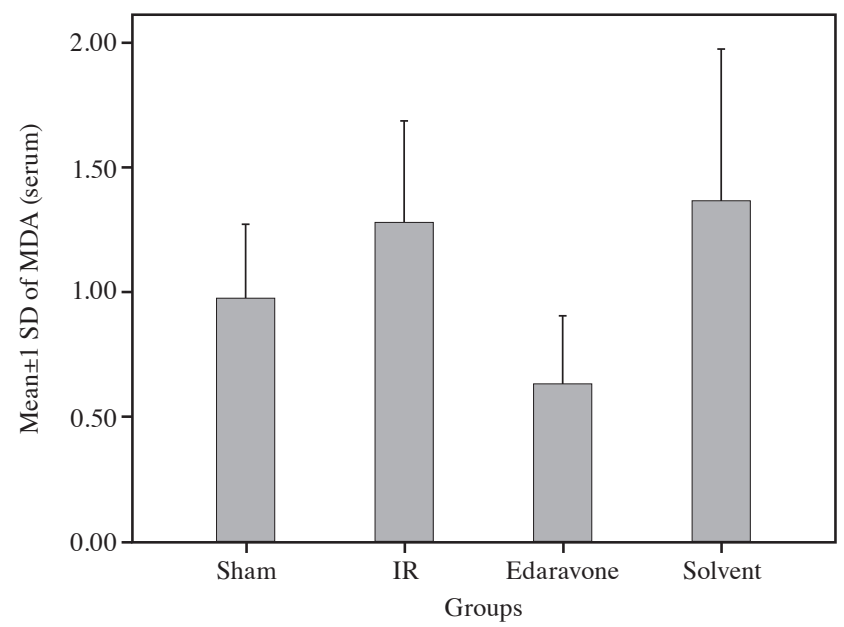

Figure 1. Bar graph of MDA (serum) with mean \pm 1 standard deviation.

SD: Standard deviation; MDA: Malondialdehyde. 


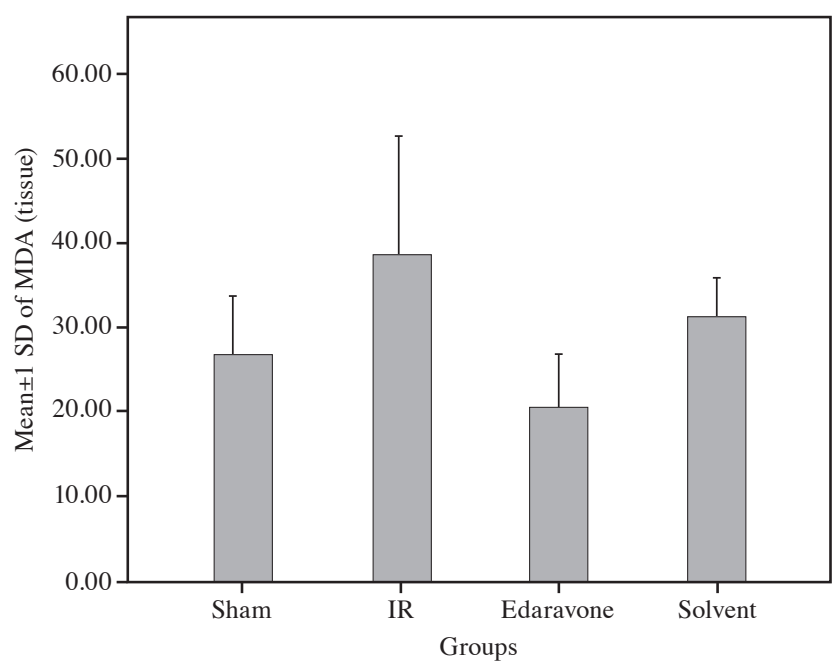

Figure 2. Bar graph of MDA (tissue) with mean \pm 1 standard deviation.

SD: Standard deviation; MDA: Malondialdehyde.

\section{Histopathological examination}

Tissue samples were subjected to the routine follow-up procedure after fixation in $10 \%$ formaldehyde. The tissues were embedded in paraffin blocks and sectioned in $4-\mu \mathrm{m}$ thickness. The sections were deparaffinized, stained with hematoxylin-eosin, and visualized by light microscopy. A modified version of the scoring system of Kocoglu et al. ${ }^{[7]}$ was used for pathological evaluation of the severity of kidney injury. Histological changes were evaluated by enumerating necrotic and apoptotic cells, loss of tubular brush border, tubular dilatation, cast formation, and

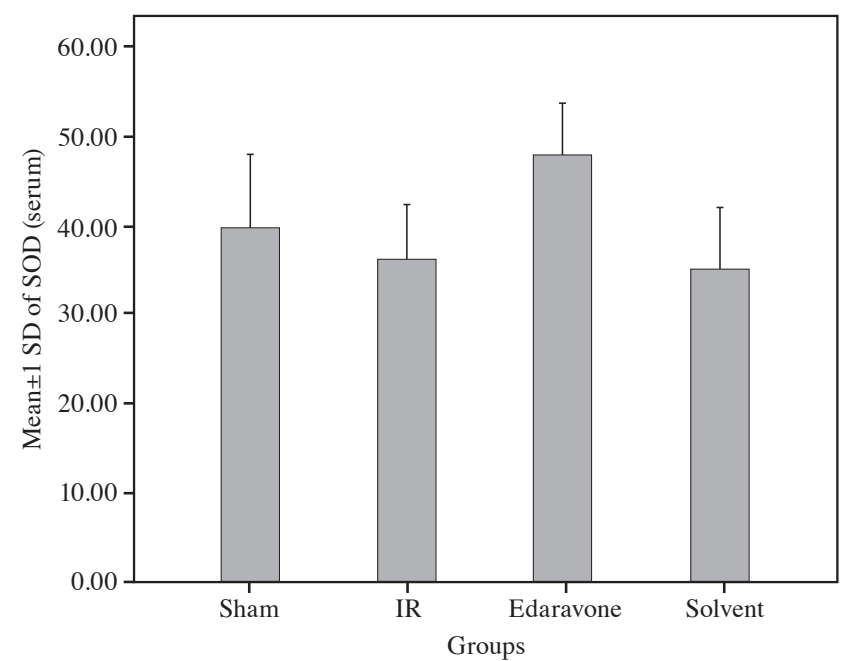

Figure 3. Bar graph of SOD (serum) with mean \pm 1 standard deviation.

SD: Standard deviation; SOD: Superoxide dismutase.

neutrophil infiltration. The scoring for kidney injury was as follows: 0 , none; $1,0-10 \% ; 2,11-25 \%$; 3, 26-45\%; 4, 46-75\%; and 5, 76-100\%.

\section{Statistical analysis}

Statistical analysis was performed using the IBM SPSS version 19.0 software (IBM Corp., Armonk, NY, USA). Continuous variables were presented in mean \pm standard deviation (SD). As there were more than two groups, analysis of variance (ANOVA) was performed. If ANOVA indicated significance, the Tukey's Honestly Significant Difference post-hoc test was used. A $p$ value of $<0.05$ was considered statistically significant.

Table 1. Distributions of quantitative variables according to groups

\begin{tabular}{|c|c|c|c|c|c|}
\hline \multirow[b]{3}{*}{ Variables } & \multicolumn{4}{|c|}{ Groups } & \multirow[b]{3}{*}{$p$} \\
\hline & Sham $(n=10)$ & IR $(n=10)$ & Edaravone $(\mathrm{n}=10)$ & Solvent $(n=10)$ & \\
\hline & Mean \pm SD & Mean \pm SD & Mean \pm SD & Mean \pm SD & \\
\hline Injury score & $0.2 \pm 0.4^{\mathrm{b}}$ & $3.3 \pm 0.7^{\mathrm{a}}$ & $1.6 \pm 0.5^{\mathrm{c}}$ & $2.7 \pm 0.7^{\mathrm{a}}$ & $<0.001$ \\
\hline Superoxide dismutase (serum) & $4.0 \pm 1.1^{\mathrm{ab}}$ & $3.6 \pm 0.9^{\mathrm{a}}$ & $4.8 \pm 0.8^{b}$ & $3.5 \pm 1.0^{\mathrm{a}}$ & 0.020 \\
\hline Glutathione peroxidase (serum) & $9.1 \pm 3.1$ & $8.3 \pm 4.8$ & $14.0 \pm 8.4$ & $8.5 \pm 5.1$ & 0.097 \\
\hline Nitric oxide (serum) & $22.5 \pm 9.7^{\mathrm{a}}$ & $28.7 \pm 13.6^{\mathrm{ac}}$ & $23.4 \pm 8.3^{\mathrm{a}}$ & $38.5 \pm 19.8^{\mathrm{bc}}$ & 0.046 \\
\hline Malondialdehyde (serum) & $1.0 \pm 0.4^{\mathrm{a}}$ & $1.3 \pm 0.6^{\mathrm{b}}$ & $0.6 \pm 0.4^{\mathrm{a}}$ & $1.4 \pm 0.9^{b}$ & 0.034 \\
\hline Superoxide dismutase (tissue) & $15.6 \pm 2.6$ & $14.1 \pm 1.2$ & $15.2 \pm 2.1$ & $13.9 \pm 1.2$ & 0.145 \\
\hline Glutathione peroxidase (tissue) & $14.6 \pm 3.5$ & $12.6 \pm 2.0$ & $14.1 \pm 2.4$ & $12.8 \pm 1.7$ & 0.239 \\
\hline Nitric oxide (tissue) & $57.7 \pm 8.9^{a}$ & $76.2 \pm 16.2^{\mathrm{b}}$ & $69.8 \pm 10.5^{\mathrm{ab}}$ & $65 \pm 10.3^{\mathrm{ab}}$ & 0.010 \\
\hline Malondialdehyde (tissue) & $26.9 \pm 7.0^{\mathrm{ac}}$ & $38.7 \pm 14.1^{\mathrm{b}}$ & $20.7 \pm 6.3^{c}$ & $31.4 \pm 4.6^{\mathrm{ab}}$ & $<0.001$ \\
\hline
\end{tabular}

For groups, different superscripts $(a, b, c)$ in the same row (ANOVA) indicate a statistical significant difference. 


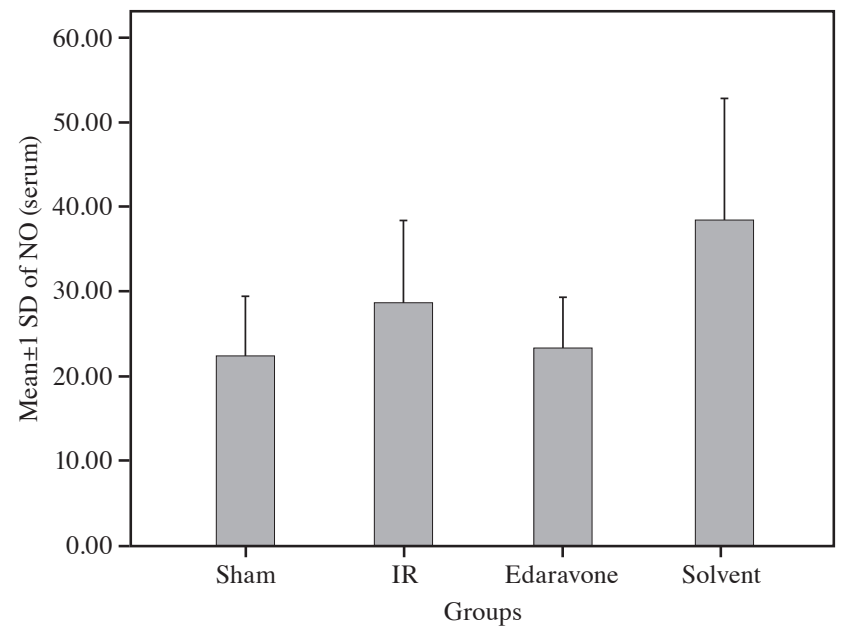

Figure 4. Bar graph of $\mathrm{NO}$ (serum) with mean \pm 1 standard deviation.

SD: Standard deviation; NO: Nitric oxide.

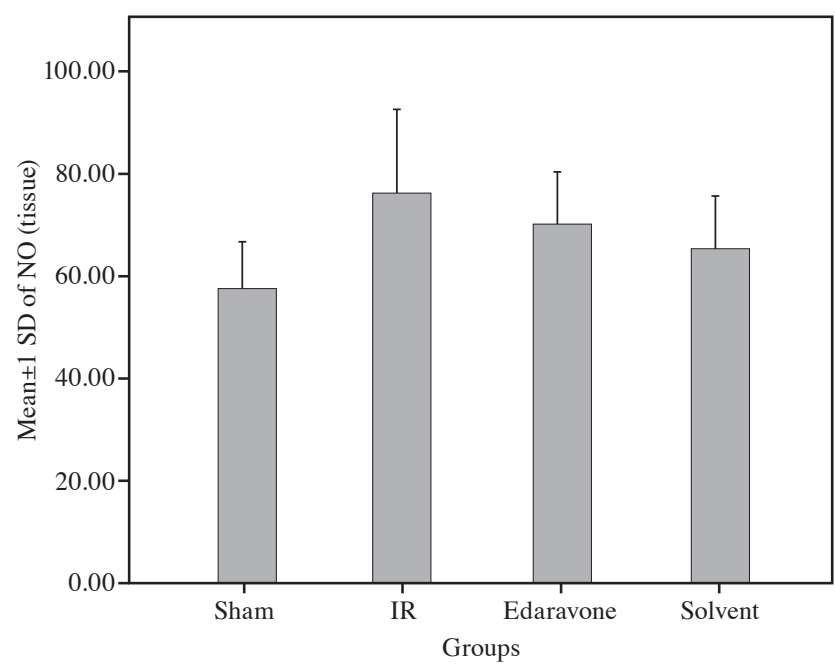

Figure 5. Bar graph of $\mathrm{NO}$ (tissue) with mean \pm 1 standard deviation.

SD: Standard deviation; NO: Nitric oxide.

\section{RESULTS}

\section{Biochemical results}

The serum and tissue MDA levels were higher in the $I / R$ than in the sham group $(p=0.034$, $<0.001$ ) (Figures 1 and 2). However, the serum and tissue MDA levels were significantly lower in the edaravone group than in the $I / R$ group $(p<0.001)$ (Figures 1 and 2). The serum SOD activity in the edaravone group was significantly higher than that in the $I / R$ and solvent groups $(p=0.020)$ (Figure 3). There were no significant differences in the tissue SOD levels or the serum and tissue GPx levels among

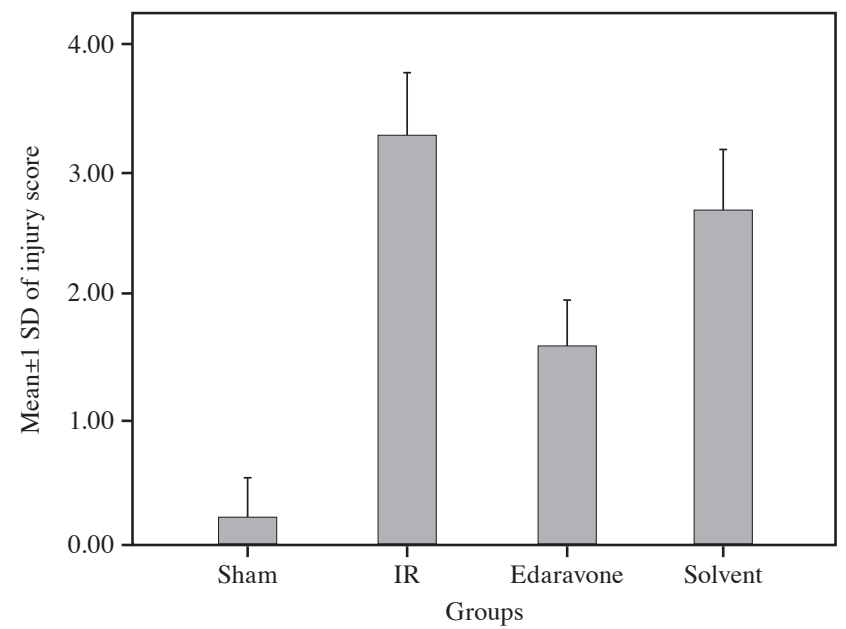

Figure 6. Bar graph of Injury score with mean \pm 1 standard deviation.

SD: Standard deviation.

the groups $(\mathrm{p}=0.097)$. The serum NO level in the $\mathrm{I} / \mathrm{R}$ group was numerically higher than that in the sham group. Although not significant, edaravone decreased the serum NO levels (Table 1) (Figure 4). Compared to the solvent group, the NO level was lower in the edaravone group $(\mathrm{p}=0.046)$; however, it did not differ significantly between the I/R and solvent groups. The tissue NO level was significantly higher in the I/R than in the sham group (Figures 4 and 5). There were no significant differences in the serum and tissue GPx levels among the groups (Table 1).

\section{Histopathological findings}

The histological structure in the sham group was normal, but the I/R group showed significant degeneration, necrosis of tubular epithelial cells, and inflammatory cell infiltration of the interstitial space (Figure 6). The mean renal injury score was $3.3 \pm 0.67$ in the $I / R$ group, being significantly higher than that of the sham group $(\mathrm{p}<0.001)$. In the edaravone group, the mean tissue injury score was $1.6 \pm 0.52$, being significantly lower than that of the $\mathrm{I} / \mathrm{R}$ group $(\mathrm{p}<0.001)$ (Table 1) (Figure 7), and the morphology of glomerular capillaries was normal and minimal edema and congestion were observed in the interstitial space (Figure 7). There was no significant difference in the injury scores between the I/R and solvent groups.

\section{DISCUSSION}

Distant organ injury after $\mathrm{I} / \mathrm{R}$ in the lower extremities is a serious clinical issue. Several pharmacological agents can be used to prevent the adverse effects of free oxygen radicals, which are 


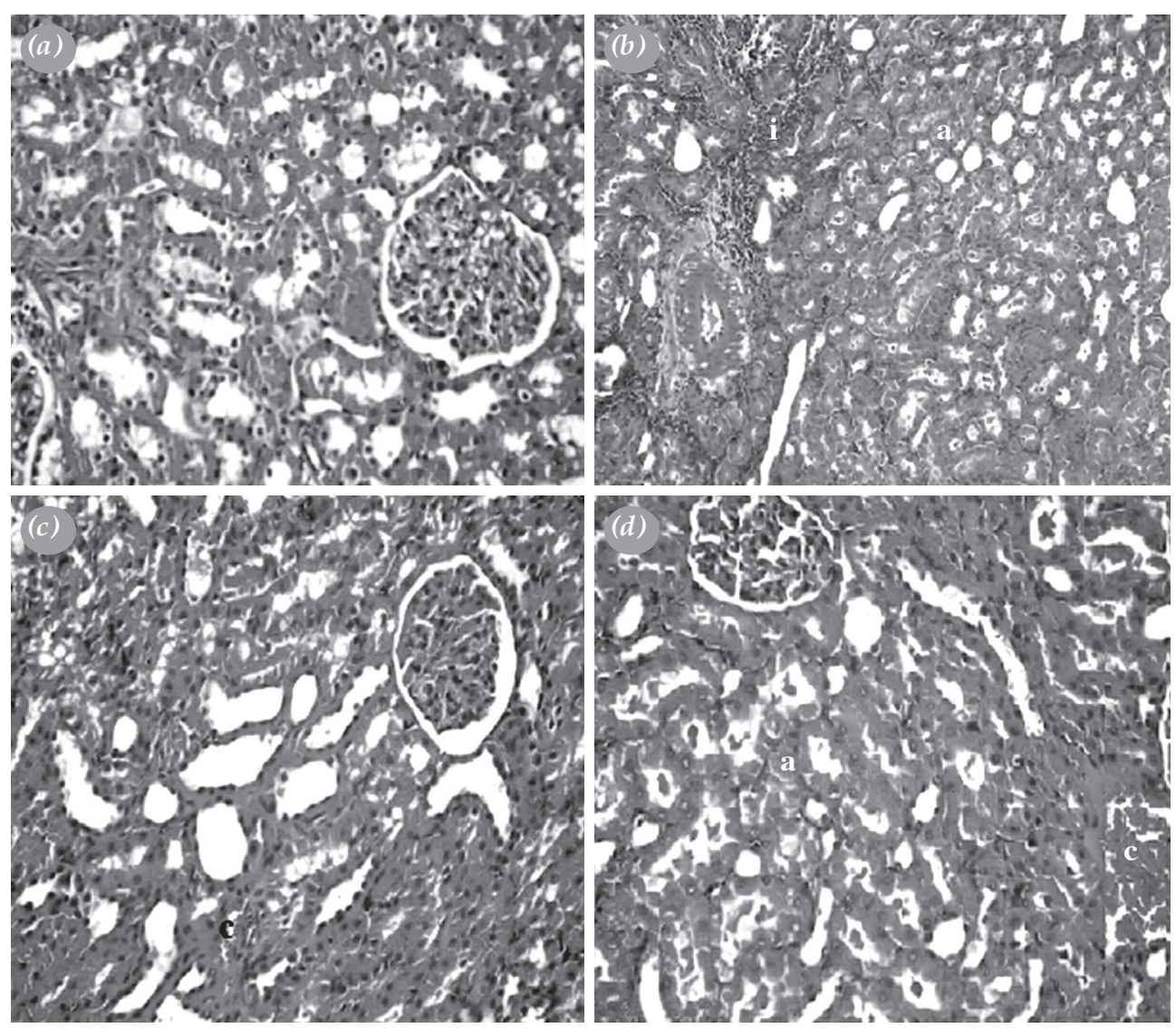

Figure 7. (a) Sham group $(\mathrm{H}-\mathrm{E} \times 400)$. (b) Ischemia/reperfusion group $(\mathrm{H}-\mathrm{E} \times 200)$. (c) Edaravone group $(\mathrm{H}-\mathrm{E} \times 400)$. (d) Solvent group $(\mathrm{H}-\mathrm{E} \times 400)$. i: Inflammatory cell infiltration; a: Degeneration and necrosis in tubular epithelial cells; c: Congestion.

responsible for $\mathrm{I} / \mathrm{R}$ injury. However, most of these agents are not used clinically. Edaravone has been applied in patients with acute ischemic stroke since April 2001 in Japan based on its neurovascular protective effects. Edaravone has antiapoptotic, anti-necrotic, anti-inflammatory, and free radicalscavenging activity in cardiovascular diseases and stroke, and protects the heart, blood vessels, and brain. ${ }^{[8]}$ Also, edaravone prevents myocardial injury following $I / R$ in patients with acute myocardial infarction. ${ }^{[8]}$ Side effects of edaravone, such as acute renal failure, liver dysfunction, acute allergic reactions, disseminated intravascular coagulation, thrombocytopenia, and leukocytopenia, occur in $>5 \%$ of patients, all in elderly patients with renal dysfunction. ${ }^{[8]}$ Previous studies used a variety of durations of ischemia and reperfusion to induce $I / R$ injury in skeletal muscle. As significant morphological changes in the muscle tissue can be seen after $2 \mathrm{~h}$ of ischemia, some studies of skeletal muscle I/R injury involved ischemia for $>2 \mathrm{~h}$. In studies of I/R injury to the skeletal muscle, irreversible histological damage and neutrophil accumulation occurred after $4 \mathrm{~h}$ of ischemia; the damage caused by ischemia for 4 or 6 $\mathrm{h}$ did not differ significantly, but irreversible damage became evident after an 8 -h ischemia. Therefore, we performed ischemia and reperfusion for $2 \mathrm{~h}$ each in this study.

Previous studies of the effects of edaravone on $\mathrm{I} / \mathrm{R}$ injury used doses of 3 to $10 \mathrm{mg} / \mathrm{kg}$, which are non-toxic to rats. ${ }^{[9]}$ Zhou et al. ${ }^{[10]}$ reported that 1 , 3 , and $9 \mathrm{mg} / \mathrm{kg}$ edaravone ameliorated I/R injury in a dose-dependent manner. In the other studies, $3 \mathrm{mg} / \mathrm{kg}$ edaravone was found to be effective against I/R. ${ }^{[11,12]}$ Ito et al. ${ }^{[13]}$ investigated the protective effect of edaravone against lung injury in a model of intestinal $I / R$ in rats, in which reperfusion was performed for $120 \mathrm{~min}$ after occlusion of the superior mesenteric artery at the junction with the abdominal aorta for $120 \mathrm{~min}$. They applied $6 \mathrm{mg} / \mathrm{kg}$ edaravone 
(the reference value used in this study) intravenously after reperfusion. The MDA level in lung tissue was significantly lower in the edaravone, compared to the I/R group.

The free radicals generated during $I / R$ injury induce the peroxidation of membrane lipids. The level of MDA, the end-product of peroxidation, is used as a marker of lipid peroxidation and, thus, of I/R injury..$^{[9]}$ Serum and tissue MDA levels were reported to increase after I/R. ${ }^{[14-16]}$ In this study, there was no significant difference in the serum MDA levels between the I/R and solvent groups; however, the serum and renal tissue MDA levels were significantly higher in the $I / R$ and solvent groups, compared to those in the sham group.

Zhang et al. ${ }^{[17]}$ reported that the serum and kidney MDA levels were significantly higher in the I/R group and significantly lower in the edaravone group after renal I/R injury. Matsuyama et al. ${ }^{[18]}$ also showed that edaravone protected against renal $\mathrm{I} / \mathrm{R}$ injury. In the present study, the MDA levels in serum and renal tissue were significantly higher in the I/R and solvent groups and significantly lower in the edaravone group. Edaravone decreased the MDA level by suppressing lipid peroxidation.

Antioxidant enzymes scavenge oxygen free radicals. The antioxidant activity of SOD depends on its conversion of superoxide to hydrogen peroxide. Huang et al., ${ }^{[16]}$ using a rat model of skeletal muscle $\mathrm{I} / \mathrm{R}$, demonstrated that the SOD activity in serum and muscle tissue was significantly lower in the I/R group than in the control group, but significantly higher in the hydrogen-rich saline group than in the I/R group. Similarly, some other studies also found decreased serum and tissue SOD activities in models of I/R injury ${ }^{[15,19]}$ In the present study, the serum SOD activity was numerically lower in the I/R and solvent groups, but significantly higher in the edaravone group compared to the I/R group. The SOD activity in the renal tissue was numerically lower in the $I / R$ group than in the control group and numerically higher in the edaravone group than in the I/R group; however, none of these differences were significant. Yurekli et al. ${ }^{[20]}$ investigated the effect of pheniramine on brain injury related to lower-extremity I/R, carried out 24-h reperfusion after 1-h ischemia. The SOD activity in the brain tissue was significantly reduced by pheniramine. The reduced SOD activity in the renal tissue in this our study may have been caused by the relatively short duration of reperfusion.

The antioxidant activity of GPx is conferred by its reduction of $\mathrm{H}_{2} \mathrm{O}_{2}$ to $\mathrm{H}_{2} \mathrm{O}$. Yurekli et al. ${ }^{[20]}$ showed that the GPx activity in the brain tissue was significantly decreased by $I / R$ and significantly increased by pheniramine. Moreover, the GPx activity in the serum and spinal cord tissue was significantly decreased by $I / R$ and significantly increased by cilostazol. ${ }^{[15]}$ In the present study, the GPx activity in serum and renal tissue was decreased in the I/R and solvent groups and increased in the edaravone group compared to the I/R group; however, the differences were not significant, likely due to the relatively short duration of reperfusion.

Nitric oxide mediates tissue damage during I/R injury; however, its cytoprotective and cytotoxic effects hamper the full elucidation of its role. Inducible NOS (iNOS) is upregulated in response to inflammatory stimuli such as endotoxins, cytokines, and lipid mediators. Surges in NO production mediated by iNOS are cytotoxic and have been implicated in inflammatory damage to the heart, kidney, liver, brain, intestine, and skeletal muscle. During the later stages of reperfusion, production of proinflammatory cytokines induces the expression of iNOS, leading to high (picomolar) concentrations of NO. This is converted to peroxynitrite and other products with pro-oxidant activity, leading to tissue destruction. ${ }^{[21]}$ Skeletal muscle is reportedly impacted by the NO generated by iNOS. Barker et al. ${ }^{[22]}$ reported that the area of necrosis was greater in wild-type mice than in iNOS-knockout mice, the difference being significant after 90 min of ischemia. Hori et al. ${ }^{[23]}$ demonstrated that the iNOS level was increased by I/R and decreased by edaravone. Kirisci et al. ${ }^{[24]}$ evaluated the effect of adrenomedullin on $\mathrm{I} / \mathrm{R}$ injury in the skeletal muscle of rats; the NO level in muscle tissue was significantly higher in the I/R group, compared to the control group and significantly lower in the adrenomedullin group, compared to the I/R group. The NO level in the rat lung was reported to be significantly increased by $I / R$ and significantly decreased by melatonin. ${ }^{[25]}$ In the present study, edaravone decreased the serum and tissue NO levels after I/R.

Inflammatory mediators transported in blood from muscle tissue cause injury to distant organs, principally the lungs and kidneys. ${ }^{[26]}$ Ischemia/reperfusion injury induces acute kidney injury. Renal tubules are susceptible to ischemia, and $I / R$ results in the death of epithelial cells in tubular regions. ${ }^{[27]}$ Kocoglu et al. $^{[7]}$ induced renal $\mathrm{I} / \mathrm{R}$ injury by clamping and declamping the renal artery; the kidneys of rats with untreated I/R injury exhibited tubular cell swelling, cellular vacuolization, pyknotic nuclei, medullary congestion, and moderate-to-severe necrosis. Khajuria 
et al ${ }^{[28]}$ reported the swelling of tubular cells, medullar congestion, and renal cell necrosis in renal tissue affected by $I / R$. In a model of myonephropathic metabolic syndrome, which was induced by clamping the bilateral common femoral arteries for $5 \mathrm{~h}$ followed by the removal of the clamp to allow reperfusion, edaravone ameliorated renal tissue damage by reducing cellular infiltration. ${ }^{[29]}$ In our I/R model, significant degeneration and necrosis of tubular epithelial cells and inflammatory cell infiltration of the interstitial space in the renal tissue were observed. Edaravone restored the normal morphology of glomerular capillaries and reduced edema and congestion in the interstitial space. In addition, edaravone significantly decreased the renal injury score.

There are some limitations to this study. In this study, only $6 \mathrm{mg} / \mathrm{kg}$ edaravone was used and, therefore, further studies should evaluate the effects of other doses of edaravone. In addition, we were able to evaluate only one duration of $I / R$ and further studies examining the impact of edaravone on $\mathrm{I} / \mathrm{R}$ of different durations are warranted.

In conclusion, edaravone ameliorated renal injury caused by lower-limb ischemia/reperfusion in our study. Therefore, edaravone has a potential for treating acute ischemia/reperfusion injury during aortic and peripheral vascular surgery, although further studies are still needed to confirm these findings.

\section{Declaration of conflicting interests}

The authors declared no conflicts of interest with respect to the authorship and/or publication of this article.

\section{Funding}

The authors received no financial support for the research and/or authorship of this article.

\section{REFERENCES}

1. Gülmen Ş, Doğuç Kumbul D, Ceylan Gökçe B, Çetin Kahraman N, Meteoğlu İ, Okutan H, et al. The effect of betaglucan on kidney injury in experimental aortic ischemiareperfusion. Turk Gogus Kalp Dama 2011;19:234-41.

2. Mansour Z, Charles AL, Kindo M, Pottecher J, ChamarauxTran TN, Lejay A, et al. Remote effects of lower limb ischemia-reperfusion: impaired lung, unchanged liver, and stimulated kidney oxidative capacities. Biomed Res Int 2014;2014:392390.

3. Nishi H, Watanabe T, Sakurai H, Yuki S, Ishibashi A. Effect of MCI-186 on brain edema in rats. Stroke 1989;20:1236-40.

4. Abe T, Unno M, Takeuchi H, Kakita T, Katayose Y, Rikiyama $\mathrm{T}$, et al. A new free radical scavenger, edaravone, ameliorates oxidative liver damage due to ischemia-reperfusion in vitro and in vivo. J Gastrointest Surg 2004;8:604-15.
5. Masaki Y, Kumano K, He N, Suyama I, Endo T. Protective effects of MCI-186 on cold kidney preservation/reperfusion injury in the rat. Transplant Proc 1996;28:1885-6.

6. Doi K, Suzuki Y, Nakao A, Fujita T, Noiri E. Radical scavenger edaravone developed for clinical use ameliorates ischemia/reperfusion injury in rat kidney. Kidney Int 2004;65:1714-23.

7. Kocoglu H, Ozturk H, Ozturk H, Yilmaz F, Gulcu N. Effect of dexmedetomidine on ischemia-reperfusion injury in rat kidney: a histopathologic study. Ren Fail 2009;31:70-4.

8. Kikuchi K, Tancharoen S, Takeshige N, Yoshitomi M, Morioka M, Murai Y, et al. The efficacy of edaravone (radicut), a free radical scavenger, for cardiovascular disease. Int J Mol Sci 2013;14:13909-30.

9. Tabrizchi R. Edaravone Mitsubishi-Tokyo. Curr Opin Investig Drugs 2000;1:347-54.

10. Zhou S, Yu G, Chi L, Zhu J, Zhang W, Zhang Y, et al. Neuroprotective effects of edaravone on cognitive deficit, oxidative stress and tau hyperphosphorylation induced by intracerebroventricular streptozotocin in rats. Neurotoxicology 2013;38:136-45.

11. Kassab AA, Aboregela AM, Shalaby AM. Edaravone attenuates lung injury in a hind limb ischemia-reperfusion rat model: A histological, immunohistochemical and biochemical study. Ann Anat 2020;228:151433.

12. Yamamura M, Miyamoto Y, Mitsuno M, Tanaka H, Ryomoto M. Pretreatment with the Free Radical Scavenger Edaravone Mitigates Kidney Glycogen Depletion and Neutrophil Infiltration after Leg Ischemia in a Rat Model: A Pilot Study. Ann Vasc Dis 2017;10:417-22.

13. Ito K, Ozasa H, Horikawa S. Edaravone protects against lung injury induced by intestinal ischemia/reperfusion in rat. Free Radic Biol Med 2005;38:369-74.

14. Koksal C, Bozkurt AK, Ustundag N, Konukoglu D, Musellim $\mathrm{B}$, Sirin $\mathrm{G}$, et al. Attenuation of acute lung injury following lower limb ischemia/reperfusion: the pharmacological approach. J Cardiovasc Surg (Torino) 2006;47:445-9.

15. Nazli Y, Colak N, Namuslu M, Erdamar H, Haltas H, Alpay MF, et al. Cilostazol attenuates spinal cord ischemiareperfusion injury in rabbits. J Cardiothorac Vasc Anesth 2015;29:351-9.

16. Huang T, Wang W, Tu C, Yang Z, Bramwell D, Sun X. Hydrogen-rich saline attenuates ischemia-reperfusion injury in skeletal muscle. J Surg Res 2015;194:471-80.

17. Zhang G, Xu QP, Huang HY. Protective effects of edaravone on renal ischemia-reperfusion injury in rats. Zhejiang Da Xue Xue Bao Yi Xue Ban 2008;37:308-11.

18. Matsuyama M, Hayama T, Funao K, Tsuchida K, Takemoto Y, Sugimura K, et al. Treatment with edaravone improves the survival rate in renal warm ischemia-reperfusion injury using rat model. Transplant Proc 2006;38:2199-200.

19. Avci T, Erer D, Kucuk A, Oztürk Y, Tosun M, Oktar GL, et al. The effects of iloprost on ischemia-reperfusion injury in skeletal muscles in a rodent model. J Surg Res 2014;187:162-8.

20. Yürekli I, Gökalp O, Kiray M, Gökalp G, Ergüneş K, Salman $\mathrm{E}$, et al. Effect of pheniramine maleate on reperfusion injury in brain tissue. Med Sci Monit Basic Res 2013;19:285-90. 
21. Khanna A, Cowled PA, Fitridge RA. Nitric oxide and skeletal muscle reperfusion injury: current controversies (research review). J Surg Res 2005;128:98-107.

22. Barker JE, Knight KR, Romeo R, Hurley JV, Morrison WA, Stewart AG. Targeted disruption of the nitric oxide synthase 2 gene protects against ischaemia/reperfusion injury to skeletal muscle. J Pathol 2001;194:109-15.

23. Hori K, Tsujii M, Iino T, Satonaka H, Uemura T, Akeda K, et al. Protective effect of edaravone for tourniquet-induced ischemia-reperfusion injury on skeletal muscle in murine hindlimb. BMC Musculoskelet Disord 2013;14:113.

24. Kirisci M, Oktar GL, Ozogul C, Oyar EO, Akyol SN, Demirtas CY, et al. Effects of adrenomedullin and vascular endothelial growth factor on ischemia/reperfusion injury in skeletal muscle in rats. J Surg Res 2013;185:56-63.

25. Takhtfooladi H, Takhtfooladi M, Moayer F, Mobarakeh S. Melatonin attenuates lung injury in a hind limb ischemia- reperfusion rat model. Rev Port Pneumol 2015;21:30-5.

26. Homer-Vanniasinkam S, Crinnion JN, Gough MJ. Postischaemic organ dysfunction: a review. Eur J Vasc Endovasc Surg 1997;14:195-203.

27. Wan X, Hou LJ, Zhang LY, Huang WJ, Liu L, Zhang Q, et al. IKK $\alpha$ is involved in kidney recovery and regeneration of acute ischemia/reperfusion injury in mice through IL10-producing regulatory $\mathrm{T}$ cells. Dis Model Mech 2015;8:733-42.

28. Khajuria A, Tay C, Shi J, Zhao H, Ma D. Anesthetics attenuate ischemia-reperfusion induced renal injury: effects and mechanisms. Acta Anaesthesiol Taiwan 2014;52:176-84.

29. Yamamura M, Miyamoto Y, Mitsuno M, Tanaka H, Ryomoto M. Edaravone protects against tissue damage in the lung and kidney induced by myonephropathic metabolic syndrome. Int J Angiol 2010;19:e38-40. 